\title{
Contending Issues Relating to Copyright Ownership in Commissioned Works in Nigeria: A Case of Robbing Peter to Pay
}

\section{Job O Odion*}

Department of Business Law, University of Benin, Nigeria

\begin{abstract}
This article examined the conflict between the similar though not conterminous concepts of authorship and ownership of copyright works. This is done against the background that though it is assumed that authorship and ownership of copyright can exist in the same persons, in appropriate circumstances two different persons can lay claim separately to the authorship and ownership of copyright. Whereas it is presumed that the author of copyright is the owner of the right therein, there are also circumstances in which an author may be denied of his ownership of copyright therein. No other form of copyright incidence epitomizes this anomaly than the relationship between a commissioner of copyright work and the commissionee. This is the basis of our analysis.
\end{abstract}

Keywords: Copyright; Ownership; Copyright infringement; Law

\section{Introduction}

The activities of the National Copyright Commission in the protection of the rights of copyright owners in copyright works have improved in recent times [1]. The news reports are awash with the seizure of pirated copies of musical film and works as well as plagiarised literary works [2]. There has been a renewed drive towards the arrest and prosecution of persons who deliberately pirate or plagiarised copyright works in the country [3]. There is equally a renewed drive towards a compulsory registration of copyright works in the country.

Whilst the criminal sanctions for copyright infringement had always taken a centre stage in the country, so much cannot be said of the civil remedies of victims of infringement of this copyright works. There have been less civil litigations over issues of copyright infringement with the accordant consequence of a death of rich literature and jurisprudence on the nature and scope of civil remedies for copyright infringement in the country [4].

No doubt, in civil actions anchored on alleged infringement of copyright in an existing work, questions of who is actually the owner of the said work are bound to arise. Since registration is not a condition precedent to the recognition and protection of copyright, the question of who is the author and owner of a copyright in an existing work often revolves around issues of evidence and the courts attitude to the facts presented before it. It is the courts that would ultimately decide whether the work or contribution to an existing work by a person is original in character to warrant its recognition and protection as copyright [5]. It is equally based on the nature of evidence proffered by the contending parties that would enable the court determine who amongst they expressed the idea in a definite medium of expression in order to satisfy the additional requirement and protection of copyright [6].

However, in resolving issues relating to authorship and ownership of copyright, there is the contending issue as to whether the author of a work is automatically entitled to copyright therein. Whereas, it is the policy to reward the author of a work with copyright therein, it is now possible for a non-author to lay claim to ownership of copyright therein. This could be possible where such a person is granted an exclusive licence to use the work in accordance with the law or is a beneficiary of an assignment or transmission of interest in the copyright work. Whereas these scenarios are well settled, it is in respect of the claim to ownership of copyright in commissioned works by a commissioner in difference to the right of the author (the commissionee) that there appears to be some controversy. One of the issues the courts are often confronted with is ownership with respect to commissioned works or works carried out by an employee whilst in the course of his employment. Contentious issues have often arisen as to who as between the commissioner or commissionee of copyright works is the owner of the copyright in the work. Similar questions have also arisen as to who as between the employer and the employee is the owner of copyright in works created by the employee in the course of his employment. This is because in the context of our analysis, the employer could be the commissioner whilst the employee could be the commissionee. Thus an examination of the legal issues relating to the ownership of copyright in such works is appropriate here. This article examines these contending issues, particularly with respect to the stance of the courts in the resolution of such conflict.

\section{Theoretical Framework}

There has always being controversy as to the applicable principle governing the competing claims to copyright ownership in works created by a commissioner of works of copyright as well as copyright work created by employees under contract of employment. Under the 1911 Copyright Act in England, there was the concept of implied assignment of copyright in works commissioned. Accordingly a commissionee who was given the mandate or duty to create a work was held to hold the copyright in the work so created on behalf of the commissioner [7]. The presumption was that it is the commissioner who invested his money, materials and resources in the creation of the work that should enjoy the copyright in the works. This was because copyright in that context was seen as a business venture in which the commissioner was an entrepreneur who ought to be allowed to reap the fruits of his investment [8]. Conversely, it was equally the policy at that time to encourage such entrepreneurial investment, as to do otherwise

${ }^{*}$ Corresponding author: Odion JO, Senior Lecturer, Department of Business Law, University of Benin, Nigeria, Tel: +234 709880 5057; E-mail: job.odion@uniben.edu

Received November 03, 2016; Accepted January 05, 2017; Published January 13, 2017

Citation: Odion JO (2017) Contending Issues Relating to Copyright Ownership in Commissioned Works in Nigeria: A Case of Robbing Peter to Pay. Intel Prop Rights. 5: 174. doi: 10.4172/2375-4516.1000174

Copyright: (@ 2017 Odion JO. This is an open-access article distributed under the terms of the Creative Commons Attribution License, which permits unrestricted use, distribution, and reproduction in any medium, provided the original author and source are credited. 
would have meant fewer people investing their money and materials in research, and craftsmanship.

Furthermore, the policy of assuming that the "commissioner" was the owner of the work was equally justified on the basis that copyright did not protect ideas in their incubated or inchoate state, but in the expression of such ideas through or in a definite medium. Accordingly, ideas no matter how ingenious and lofty remained ideas unless and until they are expressed in definite medium of expression, from which they could be expressed and appreciated. Therefore, whoever finances or make it possible for such ideas to be fixated and cognisable, deserve some measure of protection under the law [9].

However, in England, the post 1911 Copyright Act moved away from this notion of entrepreneur copyright to an acknowledgment of the efforts of the author of the work in question. Under the 1988 Copyright Act in England, the author was recognised as the first owner in any work created by him, irrespective of whether he was commissioned to do the work or whether the work was created in the course of his employment [10].

The fallout of the aforesaid was that there was the need to draw a line of distinction between "employees" simpliciter and "independent contractors". With reference to commissioned works, there was the presumption that works created by "employees" in the course of their service will belong to the said employees, unless there was an agreement to the contrary between the employee and his employer. This is aptly encapsulated by section 10 (2) (a) and (b) of the Nigerian Copyright Act, which provides inter alia;

"Notwithstanding subsection (6) of section 10 of this Act, where a work;

(a) Is commissioned by a person who is not the authors employer under a contract of service or apprenticeship

(b) Not having been so commissioned is made in the course of the author's employment.

The copyright shall belong in the first instance to the author, unless otherwise stipulated in writing under the contract.

It is assumed that by the tenor of section 10 (2) (a) the work is created by an author who is under a contract for service, which makes him an independent contractor whereas under section 10 (2) (b) the work is supposedly created by an employee who is under a contract of service. The legal import of this distinction is best appreciated when the incidence of control and supervision are imputed to these differences.

Accordingly, available literature indicates that a commissioned work is created under a contract of employment if the following features are discernible $[11,12]$.

\section{Mutuality of obligation}

It has been argued that, where the employee is under a contract where he is enjoined to work exclusively for the employer, it is a contract of service. Accordingly if the employee is under a contract in restraint of trade, (where same is permissible) he is not expected to work elsewhere or use the time and materials provided by his employer for other purposes albeit personal or otherwise [13]. Implicit in the mutuality test is that the employee is under a compulsory obligation to do that which he is instructed to do by his employer. Therefore, once the job description falls within his scope of authority and is in the course of his employment, it is presumed to be a work carried out by an author under a contract of employment.

\section{The control test}

The other benchmark for discerning a work subject to a contract for service from that subject to a contract of service is the "Control Test". It is suggested that where there is evidence that the commissioner of the work has some measure of control and supervision over the commissionee there is a presumption that the work was carried out under a contract of service. This is more probable in situations where the "commissioner" provides the fund and materials with which the "commissionee" created the work in question [14].

In applying this major test, it is possible that a combination of these tests would in the context of the copyright law in Nigeria negate the presumption in section 10 (2) (a) and (b) thereof that the employee is the first owner of the work so created under the contract of service. What is however innovative under section 10 (2) (b) aforesaid is that a prudent employer should go a step further to elicit a written undertaking from the employee that the work so created is ceded to the employer. This will make the curious decisions in Stevenson Jordan v. McDonald (Supra) and Noah v. Shuba (supra) [15] inapplicable in Nigeria. In this case Dr. Noah claimed for copyright infringement against his former employers in respect of a book he had written whilst working as a consultant epidemiologist. The book was entitled "A Guide to Hygienic Skin Piercing". It turned out in evidence that he wrote the book in the course of service, he discussed the work with his colleagues and above all, he used his employer's, materials in the production of this work. However, it was evident that a bulk part of the work was written by Dr. Noah at his spare time whilst on holidays. Accordingly, the trial court held that the work was not created in the course of service and that the copyright therein belonged to him and not his employers. Certainly, this decision is in synch with Section 10 (2) (a) and (b) of the Copyright Act under reference, this failure or inability of Dr. Noah's employers to rebut the presumption of first ownership in his favour is the reason for their loss at the trial of the suit.

However before this ground breaking decision, the earlier English cases of Byrne v. Statist [16], Belloff v. Pressdram [17] had created some measure of confusion on this issue. In Byrne v. Statist (supra)a journalist who undertook a piece of translation and editing of a work into Portuguese language outside his usual scope of work and outside his normal working hours, was held to have copyright in the translated work. In Belloff v. Pressdram (supra), Thejournalist in question was denied copyright ownership in the internal memorandum he generated and distributed to his colleagues whilst in employment of the defendant.

Clearly, these cases exemplified the conflict in the attempts at tilting the pendulum in favour of the creator of the work as against the person who financed the creation of the work. The "commissionee" created the work, whereas the "commissioner" financed the creation of the work. Whereas in the former case, the employer was credited with copyright in the work, in the latter, the employer was preferred. Whereas the former was decided on the 1911 Copyright Act in England, the latter was decided thereafter. However, if it is recalled that one of the benchmarks for the recognition and protection of copyright is that the work in question must be expressed in a definite medium, then it is imperative that any person who facilitates the means or process leading to the expression of the work in a definite medium ought to be recognised as the author of the work. At least, if such a person is not the sole "author" of the work in the context of section 10(1) and (2) of the Copyright Act,he should in our view be accorded the status of a "Joint author" in line with the provisions of section 11(6) of the Copyright Act. . Admittedly the "commissioner" has not created the work in the 
strict sense; neither can he pinpoint his precise contribution in the body of such a work. However, his status as a "jointauthor" it is submitted can be deciphered from his financial or moral contribution that makes it possible for the work to be created in the first place. This argument is more palpable in view of the fact that ideas no matter how lofty cannot be protected as copyright until they are expressed in a fixed medium. This arrangement it is submitted will prevent a scenario where the "commissioner" (Peter) who had invested his money and materials in the creation of a work would lose same to the "commissionee"(Paul), who will reap the benefit of such investment ultimately.

It was in order to prevent this scenario of robbing Peter to pay the Paul that the English courts devised the concept of implied trust, by construing the "commissionee" as a constructive trustee of the copyright in the work on behalf of the "commissioner" whose time, materials and money was expended in the creation of the work. Accordingly, it would be inequitable for an employee who creates a work using the time and materials of his employer to retain copyright in the work just the same way it will be adjudged inequitable for a person who had been paid for a job to retain copyright in such a work.

In the context of this article, an "employer" is viewed as a "commissioner" because it is possible that by terms of engagement his "employee" may be under an obligation to create a literary work on his behalf. In such a case the "employee" could be regarded as a "commissionee". In a classic example, the owner of a firm of Architects may engage the services of other Architects to assist him in the preparation of architectural designs. In such a scenario, it becomes necessary to determine who as between the employer/commissioner and the employee/commissionee is entitled to the ownership of copyright in such works.

In Massine v De Basil [18] a ballet dancer had sued her director, claiming ownership of copyright in the choreographic work to which he contributed. Evidence led at the trial revealed that the plaintiff as a chief dancer was on a monthly salary. The court held that the plaintiff was acting as a servant of the defendant and therefore was not entitled to copyright in the work. The Court further observed inter alia:

Even if the plaintiff could rightly be regarded as an independent contractor, it ought to be implied as a term of the agreement that any work done by the plaintiff would be done on the basis that the defendant who had paid for the work should be entitled to such rights as might arise from that payment and that he would not be deprived of the benefit of it merely on the ground that the person whom he paid was an independent contractor [19].

This shows that at common law the distinction often drawn between works created by employees who are best described as servants and those created by independent contractors was only necessary for the purposes of whether the creator of the work in question could be afforded the status of the author and copyright in the work as against being afforded the status of a constructive trustee of the copyright in the said work. In either scenario, the pervading right of the "commissioner" was never eclipsed.

\section{The Position in the United States}

In the United States, commissioned works are described as "Work for Hire" often described as (WHF). This is used to describe works created by employees as part of their job or work created on behalf of a client where all the parties agree in writing to a WHF agreement. The WHF agreement is an express exception to the presumption that works created by employees in the course of their employment belongs to them. With this arrangement the employer is not only vested with ownership of the copyright so created, he is equally deemed to be the author under what is now termed "corporate authorship" [20].

Under a WHF agreement, the actual author is precluded from publicly acclaiming his right of authorship, thus he is not only denied the legal right of ownership that is anchored on authorship, and he is equally divested of the moral right to claim ownership. However, in view of this far reaching effect of this transaction, the courts often give a restrictive interpretation to the enabling provision of the Act, which provides that a work prepared by an employee within the scope of his or her employment or work specially ordered or commissioned for use as a contribution to a collective work if the parties expressly agree in a written instrument signed by them that the work shall be considered a work made for hire [21].

This statutory provision has been subject to judicial interpretation by the courts in the United States. In Creative Non-Violence v Reid [22], the US Supreme Court in interpreting this provision held that in the first scenario contemplated under the Act, the creator of the work will be regarded as an employee, whereas in the other scenario, he will be treated as an independent contractor. Thus, the court approved of the common law analogy of agency and trusteeship in conferring ownership of copyright in such works on the commissioner and not the commissionee, even in cases where the commissionee is an independent contractor.

What is however, consolatory is that this analogy is only applicable to contracts of Work for Hire which is similar to the traditional concept of assignment of copyright work by an employee creator to his employer [23].

\section{The Position under the Copyright Act in Nigeria}

The Nigerian Copyright Act is based on the philosophy of protecting the creator of the work from those who commission him to do the work. The emphasis is more on the protection of raw talent, creativity and industry rather than the entrepreneurial skills or business acumen of the commissioner or employer. Accordingly, section 10(1) of the Act confers the first ownership of the copyright work on the author. Incidentally, the author in relation to copyright has been defined and described by specific reference to the category of copyright work in question [24]. Whereas in the case of literary, artistic and musical work, the author is the creator of the work, in respect of photographic work, the author is the person that took the photograph and in the case of sound recordings, the person who made arrangements for the sound recording. On the other hand, for sound recording of musical works, it is the person in whose name the sound recording was made.

It is therefore clear from the aforesaid, that the concept of authorship varies, though the common denominator in the first class of copyright works i. e literary, artistic and musical works, creativity and originality is the benchmark for authorship and ownership. Whereas , with regards to cinematography, sound recordings, broadcasting, entrepreneurial skills, management skills will in addition to creativity be considered in determining the author of such copyright works and ultimately the first owner of such works. This is where the dichotomy is questionable, if a man that makes arrangement for the production of a film is adjudged the author and the first owner of copyright in the film, how about the man who finances the writing and publication of a book? Has he not made arrangements for the publication of the book?

Furthermore, in order to accommodate the interest of persons who invest in the creation of copyright works, section 10 (2) (b) 
and (3) make exceptions for the implied or express assignment of copyright in works commissioned to the commissioner. By the tenor of section 10(2) (b) aforesaid, the commissioneewho is an independent contractor will not be deemed to have assigned his right in the work to the commissioner unless there is an express assignment in writing. This was precisely what happened in Ikhouria v Campaign Services Ltd and Anor [25], Here, the plaintiff was held to have expressly assigned his copyright in the photograph he took on behalf his employer because there was a clause in his employment letter making provision for such an assignment. Accordingly, by the tenor of section 10(2) (b) aforesaid, the presumption of first ownership of the work in the commissionee author is rebutted by an express assignment of the copyright by the commissionee to the commissioner [26].

However, section 10(3) of the Act creates a more direct assignment of the copyright by the commissionee to the commissioner in the circumstances restricted to the media world. By the tenor of this subsection, any literary, artistic and musical works made by an author in the course of his employment by a proprietor of a magazine, newspaper or similar periodical under a contract of service or apprenticeship and is made for the purpose of the said publication, the first ownership of copyright in the work will belong to the employer.

Certainly, this is the first direct approach at recognising the efforts of entrepreneurs and businessmen who invest in the publication of newspapers, periodicals and publications of similar pedigree. This will equally serve to protect such publishers from the vagaries of itinerant and freelance writers and journalist who may use the concept of creator-authorship as an instrument of economic blackmail and unfair competition [27].

\section{Conclusion}

We have in the course of this essay examined the "twin" concepts of "authorship" and "ownership" of copyright as they affect the rights of authors of commissioned works under the Copyright Act in Nigeria. This was done against the background of the fact that, the Copyright Act protects "owners" of copyright in any work that is cognisable and protectable at law. It was our finding that the presumption of first ownership that ensures to the commissionee is both plausible logically and under the law.

We have discovered that previously English law tried to balance the contending issues of entrepreneurship and economics with the hard work, dexterity and talent of the creator of the work. In this regard, the concept of trusteeship was used as a basis to reward an entrepreneur or employer of labour who commissions the creation of a copyright work. Through this concept of trusteeship, an employee is presumed to have ownership over the copyright work on trust for the employer who financed the creation of the work or provided the platform and/ or materials for him to create the work. This was the position under the Copyright Act of 1911 until subsequent amendments in the Copyright Act of 1956 and thereafter. Under the new dispensation in England, there is now the presumption of first ownership of copyright by creators of commissioned works irrespective of the fact that they are employees or independent contractors.

In the United States, the same principles apply, except in cases of express agreement by the commissionee under a contract for work hire, which is an acceptable situation where the commissioner of the work is adjudged to be the author and owner of copyright in such work.

We equally discovered that in the Nigeria context, the Copyright Act dispenses with the old English analogy of trusteeship and in tandem with the current position in England confers the first ownership of copyright works in the author. This is irrespective of the fact that he created the work himself or he did it on the prompting, tutelage or even the sponsorship of the employer. Thus, except in cases of direct assignment of ownership in such works, an author of copyright work in the country has his ownership rights in the work recognised and protectable.

It is our conclusion that though, entrepreneurs, industrialist and/ or employers of labour need to be encouraged to invest their time and money in the sponsorship of the creation of copyright works, this must be balanced with the primary aim of copyright law, which is to protect the original creator and author of the work.

\section{References}

1. A commissionee is the person engaged or commissioned by another called the commissioner to create a work.

2. On the catalogue of recent activities of the Nigerian Copyright Commission.

3. Onuobia F (2005) Copyright Registration in Nigeria any Benefit? Modern Practice Journal of Finance and Investment Law 9: 144-147.

4. Adedeji AA (2005) "An Examination of the Defense of FairUse to Copyright Infringement" Modern Practice Journal of Finance and Investment Law 9: 1-2.

5. Copyright Act (2012) Copyright Act Cap C28 Laws of the Federation of Nigeria 2004.

6. (a) I. C. I. C. (Directory Publishers) v Eko-Delta Nig. Ltd. (1977-1989) 2 Intelctual Property Law Report 52 (b) Peter Obe v Grapevine Communications (2003-2007) 5 Intellectual Property Law Report, 379.

7. Assien JO (2003) Copyright Law and Practice in Nigeria(Abuja,Nigerian Copyright Commission 74.

8. Donoghue v. Allied Newspaper Ltd (1938) 1 Ch. 106, also Walter v. Lane (1900) AC 339.

9. Stevenson Jordan v. McDonald (1952) 69 RPC 10, also Noah v. Shuba (1991) FSR 15.

10. Cooper M (1923) University of London Press v University Tutorials Press $2 \mathrm{Ch}$. 209, 93 LJPC 113, Walter v Lane (1900) AC 539.

11. Margoni T, Perry M (2012) Ownership in Complex Authorship:A Comparative Study of Joint Works In Copyright Law" European Intellectual Property Review 34: 22-32.

12. Ratoza M, Wilcox M (2010) Does Authorship Equate to Ownership. Advisories \& Insights, Bullivant Houser Bailey PC, USA.

13. Lexis Nexis, Carmicheal v. National Power PIc(1999) 4 ALL ER 897 (H. L).

14. Denning LJ, Jordan S, McDonald, Evans (1968) Ready Mixed Concrete (South East Ltd v. Minister of Pension of National InsuranceQBD 8 Dec 1967.

15. (1991) F. S. R. 14

16. (1914) 1 KB 622.

17. (1973) 1 ALL ER 241.

18. (1936-49) Mac. 223.

19. (1936-49) Mac. 236.

20. 17 of the United States Copyright Act, 1976

21. Garon JM (2011) The Work Made for Hire Doctrine Revisited: Startup and Technology Employees and the Use of Contracts in a Hiring Relationship. Minnesota Journal of Law and Science 12: 489-527.

22. 17 of the U.S Copyright Act.

23. 490 US 730 (1989).

24. UK Copyright, Designs and Patents Act of 1988 as amended in 2005 for similar provisions encapsulating this agency analogy.

25. 51 of the Copyright Act of Nigeria.

26. (1986)1 FHCR 308.

27. Byrne v Startist (supra). 